\title{
Phytochemical composition and antibacterial activity of ethanolic extract from trunk of Rothmannia wittii (Craib) Bremek. (Rubiaceae) newly found in Vietnam
}

\author{
Hong Thien Van ${ }^{1 *}$, Tai Thu NgUYen ${ }^{1}$, Hoai Thuong Thi Ton ${ }^{1}$, \\ Kim Truc Thi Dinh ${ }^{1}$, Van Son LE ${ }^{2}$, Tan Viet Pham ${ }^{1}$, Gia BuU Tran ${ }^{1}$ \\ ${ }^{1}$ Institute of Biotechnology and Food Technology, Industrial University of Ho Chi Minh City, Ho Chi Minh City, Vietnam \\ ${ }^{2}$ Binh Chau-Phuoc Buu Nature Reserve, Bung Rieng Ward, Ba Ria-Vung Tau Province, Vietnam
}

\begin{abstract}
Rothmannia wittii, which is found in Binh Chau-Phuoc Buu Nature Reserve, Bung Rieng ward, Xuyen Moc District, Ba Ria-Vung Tau Province, Vietnam, is a rare species of Rubiaceae family. The present study aimed to determine the phytochemical composition and antimicrobial activity of the ethanolic extract of the $R$. wittii trunk. A total of 10 compounds were identified by liquid chromatography-mass spectrophotometry (LC-MS), including 1) benzene, 1-(1,5-dimethyl-4- hexenyl)-4-methyl, 2) diphenylsulfone, 3) 63-hydroxy-10-O-acetylgenipin, 4) cinnamyl-cinnamate, 5) genipin, 6) megastigmatrienone, 7) ethyl p-methoxy-trans-cinnamate, 8) rothalazepane, 9) 1,3,6trimethylpyrano[2,3- $d$ ]imidazole-2,5(1H,3H)-dione, and 10) shanzhiol. The extract also exhibited an antibacterial activity against six bacterial strains: Bacillus cereus, Pseudomonas aeruginosa, Escherichia coli, Staphylococcus aureus, Salmonella typhimurium and Salmonella enteritidis, as determined via disk diffusion agar method.
\end{abstract}

Key words: Rothmannia wittii, extract, phytochemical composition, antibacterial activity, LC-MS

\section{Introduction}

Rothmannia Thunb., belonging to the Rubiaceae family is a genus comprising 35 species that occur primarily in temperate regions of Asia and Africa, but they more commonly grow in the Asian tropics, especially in Southeast Asia (Bui and Nguyen, 2015). In Vietnam, five species of the Rothmanniagenus are recorded: $R$. daweishanensis, R. eucodon, $R$. kampuchiana, $R$. vietnamensis, and $R$. wittii (Pham-hoang, 2000; Bui and Nguyen, 2015).

Among these species, Rothmannia wittii (Craib) Bremek. is the rare species with only few records about its location. It was firstly described in 1911 with specimens collected in Thailand (Graib, 1911). Newman et al. (2007) provided information on the distribution of this species in Laos in the A checklist of the Vascular Plant of Lao PDR. Recently, Bui and Nguyen (2015) found
$R$. wittii in Ninh Hoa District, Khanh Hoa Province, Vietnam. Furthermore, Ton et al. (2019) recorded the new distribution of this species in the Binh Chau-Phuoc Buu Nature Reserve, Bung Rieng ward, Xuyen Moc District, Ba Ria-Vung Tau Province.

Medicinal plants play an important role in healthcare worldwide. Two-third of the world's population use medicinal plants in primary health care, either to treat diseases or to maintain the good health (Oladeji, 2016). As compared to synthetic medicines, medicinal plants have better acceptability by people and good biocompatibility and adaptability, and they show lesser adverse effects. Furthermore, some modern medicine incorporate medicinal plant-derived compounds in their ingredients, such as alkaloids, phenolics, and terpenoids (Nicolaou et al., 2000). Consequently, many researchers have focused their attention on the bioactivity of medicinal plant ex-

\footnotetext{
* Corresponding author: Institute of Biotechnology and Food Technology, Industrial University of Ho Chi Minh City, 12 Nguyen Van Bao Street, Go Vap District, Ho Chi Minh City, Vietnam; e-mail: vanhongthien@iuh.edu.vn
} 
tracts and the isolation of bioactive compounds from medicinal plants for appliation in medicine and functional foods. For instance, the biological activities of many terpenoids, including antimicrobial, antiarthritic, antioxidant, anticancer, antiinflammatory, antidiabetic, anti-HIV, neuroprotective and larvicidal effects, have been demonstrated (Chirangini et al., 2004; Kamazeri et al., 2012).

$R$. wittii is a medicinal plant commonly used in traditional Thai medicine for treatment of renal disorders, sore throat, and constipation, or is used for liver detoxification and diuretic remedies (Wongsatit et al., 2002). However, the number of the studies on screening of chemical components present in $R$. wittii is still scarce, and only two studies by Kanchanapoom et al. (2002) and Chaipukdee et al. (2016) describe the chemical composition of this species. In the study of Kanchanapoom et al. (2002) on the methanolic extract of leaves and branches of $R$. wittii, the authors discovered a new compound termed it as rothwittioside (a member of tricyclic iridoid glucoside group). Chaipukdee et al. (2016) also identified two new bioactive iridoids from extract of the bark and fruit of $R$. wittii.

Accordingly, research on the chemical composition and bioactivity of other extracts of $R$. wittii, such as extracts obtained from different solvents or different parts of this species, will provide more information for further application of $R$. wittii in medicine and functional foods. In the present study, we aimed to identify the chemical composition and antibacterial activity of ethanolic extract of the $R$. wittii trunk.

\section{Materials and methods}

\section{Plant material}

Five kilograms of $R$. wittii trunks were obtained from Binh Chau-Phuoc Buu Nature Reserve, Vietnam, located at $10^{\circ} 21^{\prime} 01^{\prime \prime} \mathrm{N} ; 103^{\circ} 06^{\prime} 52^{\prime \prime} \mathrm{E}$ (Fig. 1).

\section{Tested microorganisms}

To determine the antibacterial activity of the ethanolic extract of the $R$. wittii trunk, 6 bacterial strains, including two gram-positive bacteria Bacillus cereus (ATCC 11774) and Staphylococcus aureus (ATCC 25923), and four gram-negative bacteria Salmonella enteritidis (ATCC 13076), Escherichia coli (ATCC 25922), Pseudomonas aeruginosa (ATCC 27853), and Salmonella typhimurium (ATCC 13311), were tested. The

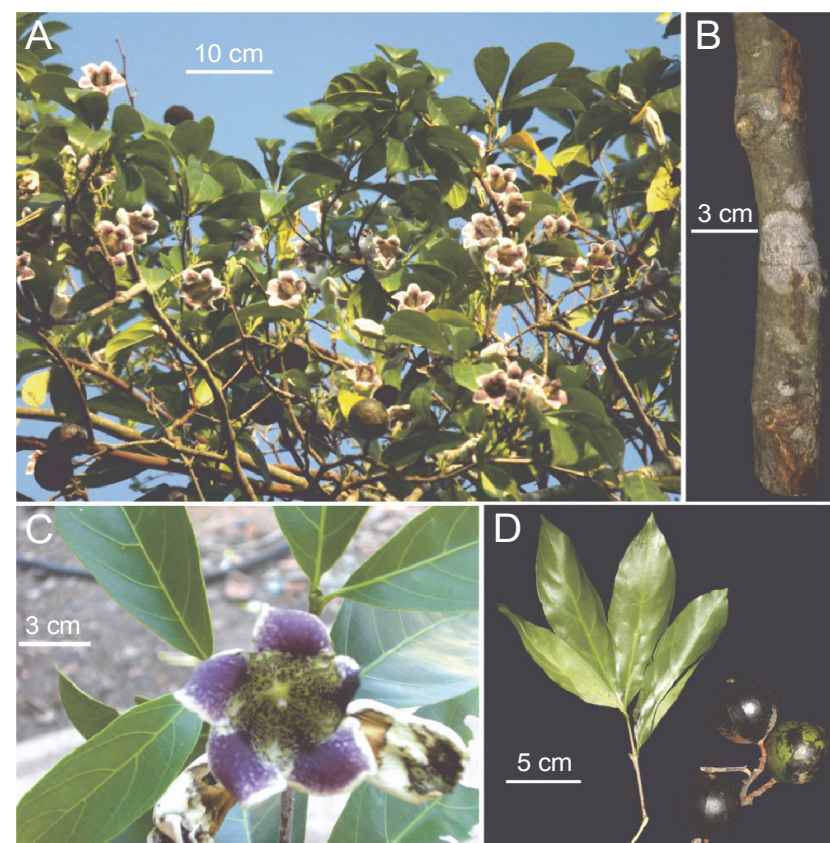

Fig. 1. Rothmannia wittii : A) habitat, B) trunk, C) flower, D) leaves and fruits

bacterial strains were provided by Department of Biotechnology, Institute of Biotechnology and Food Technology, Industrial University of Ho Chi Minh city, Vietnam. The strains were maintained in $20 \%$ glycerol solution at $20^{\circ} \mathrm{C}$ and activated by cultivation in Luria-Bertani broth at $37^{\circ} \mathrm{C}$ for $24 \mathrm{~h}$ before the antibacterial activity assay.

\section{Extraction procedure}

Fresh trunks of $R$. wittii were sliced and dried at $50^{\circ} \mathrm{C}$ until the mass of samples remained unchanged (about 5-6 days). The dried samples were pulverized into a fine powder using an electric grinder. A total of $100 \mathrm{~g}$ of the dried powder of the $R$. wittii trunks was soaked in 11 of $99 \%$ ethanol for 7 days and kept at room temperature. The extract was filtered using Whatman No. 1 filter paper. The filtrate was then concentrated under reduced pressure at 60C (Altemimi et al., 2017). The extract was subsequently subjected to sublimation drying to remove ethanol residues present in the extract. The experiments were conducted in triplicate. The resulting extract was divided into two parts; one part was used for the LC-MS analysis, and the other part was used for antibacterial assay.

\section{Liquid chromatography-mass spectrometry (LC-MS)}

To determine the chemical components of the ethanolic extract of the $R$. wittii trunk, the LC-MS analysis 
was performed. The mass spectra were compared with those from previous studies. Briefly, $20 \mu$ of the ethanolic extract was subjected to the LC-MS analysis in the HPLC Agilent 1200 infinity liquid chromatography system (Agilent Technologies, CA, USA) in tandem with MicroTOF-QII mass spectrometer (Bruker Daltonics, Germany). In the chromatographic analysis, an ACE3-C 18 analytical column $(4.6150 \mathrm{~mm}, 3.5 \mu \mathrm{m})$ was used as the stationary phase, and the mobile phase consisted of gradient solvent A (deionized water with $0.1 \%$ formic acid) and solvent B (acetonitril with $0.1 \%$ formic acid). The chromatographic separation was performed under the following conditions: flow rate: $0.3 \mathrm{ml} / \mathrm{min}$; temperature of the column: $40^{\circ} \mathrm{C}$. The electrospray ionization source (ESI) was operated in the positive mode with a mass range of $50-2000 \mathrm{~m} / \mathrm{z}$. Data acquisition was performed using Data Analysis software (Bruker, Germany).

\section{Antibacterial activity of ethanolic extract of $R$. wittii}

The antibacterial activity of the ethanolic extract of the $R$. wittii trunk against the six tested bacterial strains was evaluated following the procedure by Bauer et al. (1996) with few modifications. One colony of a bacterial strain was picked up and cultured in LB broth until the suspension turbidity reached $0.5 \mathrm{McF}$ arland standards. An aliquots of the bacterial culture $(100 \mu \mathrm{l})$ were spread on sterile Mueller Hinton plate and sterilized $6 \mathrm{~mm}$-diameter discs were placed on the inoculated surface. A total of $20 \mu \mathrm{l}$ of the ethanolic extract or diluted extracts (the extract was diluted with sterile water in the ratios of $1: 2,1: 4$, and $1: 6$ to increase the diffusion rate of the extract on agar) were added onto each disc. The inoculated plates were incubated at $4{ }^{\circ} \mathrm{C}$ for $2 \mathrm{~h}$ to allow complete diffusion of extract into the agar. The diameters of the zones of inhibition of the tested bacteria were measured and recorded after incubation at $37^{\circ} \mathrm{C}$ for $24 \mathrm{~h}$. Sterilized distilled water was used as a negative control and the commercial gentamycin antibiotic discs (Nam Khoa BioTek, Viet Nam) were used as a positive control.

\section{Statistical analysis}

All the experiments were conducted in triplicate. The results are presented as mean \pm standard deviation (SD) from triplicate analyses, and the differences among the experimental groups were determined by Fisher's least significant difference (LSD) procedure using Statgra- phics Centurion XV software (Statpoint Technologies Inc, Virginia , USA). Statistical significance was set as $P<0.05$.

\section{Results and discussion}

\section{Phytochemical analysis of ethanolic extract of the $R$. wittii trunks}

To determine the chemical constituents of ethanolic extract of the $R$. wittii trunk, the mass spectra were analyzed and compared with those of other Rothmannia species and other members of Rubiaceaefamily. As showed in Table 1 and Figure 2, the following compounds belonging to five chemical groups were identified in the ethanolic extract of $R$. wittii trunk: 1 ) iridoids (6 6 -hydroxy-10-O-acetylgenipin, genipin and shanzhiol), 2) sesquiterpene (benzene, 1-(1,5-dimethyl-4-hexenyl)-4-methyl), 3) ketones (megastigmatrienone and diphenylsulfone), 4) esters (cinnamyl-cinnamate, ethyl p-methoxytrans-cinnamate and 1,3,6-trimethylpyrano[2,3- $d$ ]imidazole-2,5(1H,3H)-dione), and 5) diterpenoids (rothalazepane).

The bioactivities of some compounds identified from the $R$. wittii trunk in this study have been documented in previous studies (Jensen, 1983; Uddin et al., 2013; Lalitha et al., 2015; Pham et al., 2015; Chaipukdee et al., 2016; Devi et al., 2016; Koagnea et al., 2017). One of the compounds, diphenylsulfone, a compound belonging to ketone group, which is found in Gnidia glauca as the major plant metabolite and exhibites the antioxidant and pesticidal activities (Ghosh et al., 2013). Moreover, some other bioactive compounds were identified in the ethanolic extract of $R$. wittii, such as cinnamyl-cinnamate, $6 \beta$-hydroxy-10-0-acetylgenipin, ethyl p-methoxytrans-cinnamate (Chaipukdee et al., 2016); these compounds exhibited an antimycobacterial activity against Mycobacterium tuberculosis. Furthermore, cinnamyl-cinnamate is a flavor ingredient that is widely used in food and cosmetics (Bhatia et al., 2007). Genipin, the aglycone iridoid derived from geniposide, exerts a strong anticancer effect against several cancer cell lines such as colorectal cancer cells, pancreatic adenocarcinoma cells, AGS and SNU638 gastric carcinoma cells, and H1299 non-small cell lung cancer cells through apoptosis, prevention of metastasis, and antiangiogenic effect (Habtemariam et al., 2018). According to Huang et al. (2008), ethyl p-methoxy-trans-cinnamate, a bioactive compound 
Table 1. Phytochemical composition of ethanolic extract of $R$. witti trunk

\begin{tabular}{l|c|l}
\hline \multicolumn{1}{c|}{ Compounds } & $\mathrm{m} / \mathrm{z}$ & \multicolumn{1}{c}{ References } \\
\hline 6ß-hydroxy-10-O-acetylgenipin & 284 & Chaipukdee et al., 2016 \\
\hline Benzene, 1-(1,5-dimethyl-4- hexenyl)-4-methyl & 202 & Lalitha et al., 2015 \\
\hline Megastigmatrienone & 190 & Lalitha et al., 2015 \\
\hline Diphenylsulfone & 218 & Devi et al., 2016 \\
\hline Cinnamyl-cinnamate & 265 & Devi et al., 2016 \\
\hline Genipin & 226 & Jensen, 1983 \\
\hline Ethyl p-methoxy-trans-cinnamate & 207 & Uddin et al., 2013 \\
\hline Rothalazepane & 205 & Koagnea et al., 2017 \\
\hline 1,3,6-Trimethylpyrano[2,3- $d$ ] imidazole-2,5(1H,3H)-dione & 195 & Pham et al., 2015 \\
\hline Shanzhiol & 264 & De et al., 2012 \\
\hline
\end{tabular}

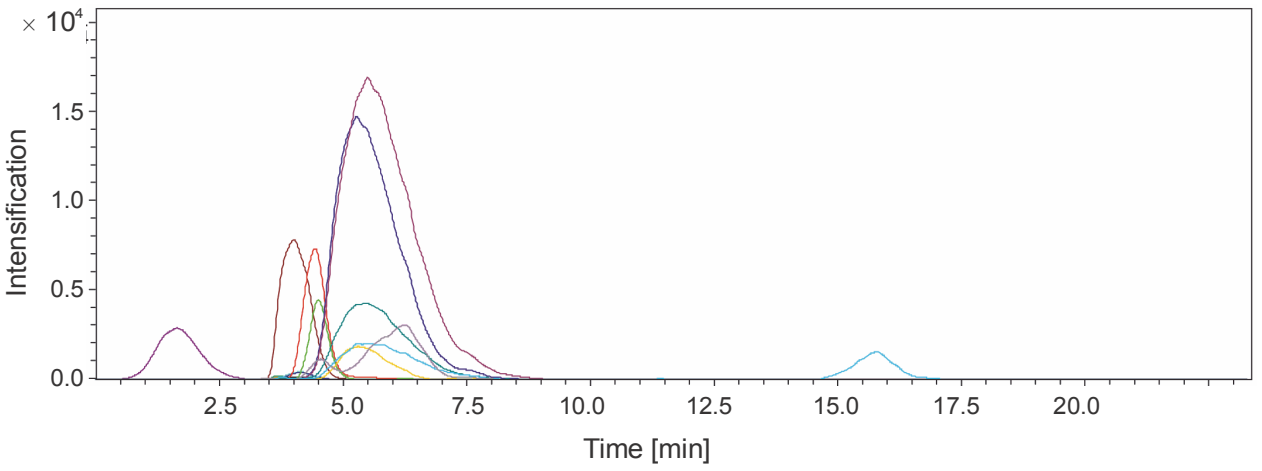

Fig. 2. Chromatogram (LC-MS) of the ethanolic extract of the $R$. wittii trunk obtained by maceration. Note: 1) benzene, 1-(1,5-dimethyl-4- hexenyl)-4-methyl; 2) diphenylsulfone; 3) 63-hydroxy-10-O-acetylgenipin; 4) cinnamyl-cinnamate; 5) ethyl p-methoxy-trans-cinnamate; 6) genipin; 7) rothalazepane; 8) megastigmatrienone; 9) 1,3,6-trimethylpyrano[2,3- $d$ ]imidazole-2,5(1H,3H)-dione; 10) shanzhiol

derived from Kaempferia galangal L., at the concentration of $0.0014 \mathrm{mg}$ has sedative and relaxant effects (Huang et al., 2008).

\section{Antibacterial activity of ethanolic extract of the $R$. wittii trunks}

The antibacterial activity of ethanolic extract of the $R$. wittii trunk was evaluated by measuring the diameters of the zones of inhibition the growth of tested bacteria (Table 2 and Fig. 3). The results showed that ethanolic extract of the $R$. wittii trunk could inhibit the growth of the six tested bacteria, namely $S$. enterritidis, $B$. cereus, $E$. coli, $P$. aeruginosa, $S$. typhimurium, and $S$. aureus. However, the diameters of the inhibition zones were varied for different bacterial strains and dilution factors. The original extract exhibited a strong antibacterial effect on all the tested bacteria, whereas the diluted extract $(1: 6)$ did not show any inhibitory effect on the growth of the tested bacterial starins, except for $B$. cereus.

Among six tested bacterial strains, the original ethanolic extract showed the strongest inhibitory effect on B. cereus $(10.3 \pm 0.3 \mathrm{~mm})$, followed by $E$. coli $(9.3 \pm$ $0.3 \mathrm{~mm}), S$. enteritidis $(9.2 \pm 0.3 \mathrm{~mm}), P$. aeruginosa $(9.2 \pm 0.3 \mathrm{~mm}), S$. typhimurium $(8.3 \pm 0.6 \mathrm{~mm})$ and $S$. aureus $(8.2 \pm 0.3 \mathrm{~mm})$. As shown in Fig. $3 \mathrm{~B}$, the original extract and diluted extract $(1: 2)$ showed the highest antibacterial activity against $B$. cereus $(10.2 \pm 0.6 \mathrm{~mm})$, whereas the increase in the dilution ratio of the extract $1: 4$ or $1: 6$ resulted in a the decrease in antibacterial activity of $8.2 \pm 0.3 \mathrm{~mm}$ and $8.0 \pm 1.0 \mathrm{~mm}$, respectively. Furthermore, the original extract exhibited the moderate antibacterial activity against $S$. enteritidis and $E$. coli 
Table 2. Inhibition zone of ethanolic extract of $R$. wittii trunk against six tested bacterial strains

\begin{tabular}{l|c|c|c|c|c|c}
\hline \multirow{2}{*}{ Tested strains } & \multicolumn{7}{|c}{ Growth inhibition zone [mm] } \\
\cline { 2 - 7 } & $\begin{array}{c}\text { negative } \\
\text { control }\end{array}$ & $\begin{array}{c}\text { positive } \\
\text { control }\end{array}$ & $\begin{array}{c}\text { original } \\
\text { extract }\end{array}$ & $\begin{array}{c}\text { diluted } \\
\text { extract } \\
(1: 2)\end{array}$ & $\begin{array}{c}\text { diluted } \\
\text { extract } \\
(1: 4)\end{array}$ & $\begin{array}{c}\text { diluted } \\
\text { extract } \\
(1: 6)\end{array}$ \\
\hline S. enteritidis & - & $7.8 \pm 0.3^{\mathrm{a}}$ & $9.2 \pm 0.3^{\mathrm{b}}$ & $8.3 \pm 0.6^{\mathrm{a}}$ & $7.8 \pm 0.3^{\mathrm{a}}$ & - \\
\hline B. cereus & - & $9.7 \pm 0.3^{\mathrm{b}}$ & $10.3 \pm 0.3^{\mathrm{b}}$ & $10.2 \pm 0.6^{\mathrm{b}}$ & $8.2 \pm 0.3^{\mathrm{a}}$ & $8.0 \pm 1.0^{\mathrm{a}}$ \\
\hline$P$. aeruginosa & - & $9.0 \pm 0.9^{\mathrm{a}}$ & $9.2 \pm 0.3^{\mathrm{a}}$ & $8.3 \pm 0.6^{\mathrm{a}}$ & - & - \\
\hline E. coli & - & $9.3 \pm 0.5^{\mathrm{b}}$ & $9.3 \pm 0.3^{\mathrm{b}}$ & $8.3 \pm 0.6^{\mathrm{a}}$ & $7.8 \pm 0.3^{\mathrm{a}}$ & - \\
\hline$S$. aureus & - & $7.2 \pm 0.3^{\mathrm{a}}$ & $8.2 \pm 0.3^{\mathrm{b}}$ & - & - & - \\
\hline$S$. typhimurium & - & $10.8 \pm 0.8^{\mathrm{c}}$ & $8.3 \pm 0.6^{\mathrm{b}}$ & $7.3 \pm 0.3^{\mathrm{a}}$ & $7.2 \pm 0.6^{\mathrm{ab}}$ & - \\
\hline
\end{tabular}

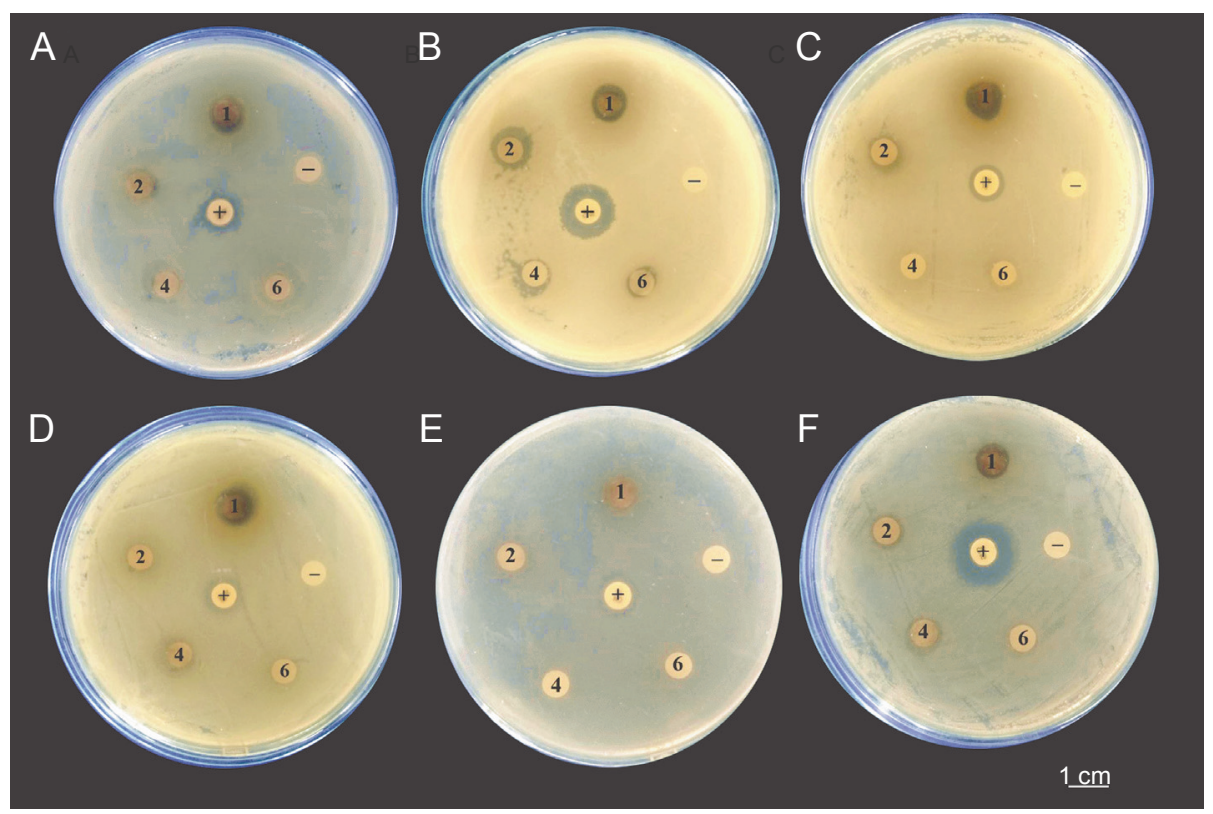

Fig. 3. Antibacterial activity of ethanolic extract of the $R$. wittii trunk against tested bacteria: A) Salmonela enteritidis, B) Bacillus cereus, C) Pseudomonas aeruginosa, D) Escherichia coli, E) Staphylococcus aureus, F) Salmonela typhimurium; the paper discs numbered as $1,2,4$, and 6 were loaded with original extract, two-fold diluted extract, four-fold diluted extract, and six-fold diluted extracts, respectively; $(-)$ negative control with sterilized distilled water, $(+)$ positive control with discs containing gentamicin

where as the diluted extracts $(1: 2)$ and $(1: 4)$ showed a low inhibitory effect on bacterial growth $(8.3 \pm 0.6 \mathrm{~mm}$ and $7.8 \pm 0.3 \mathrm{~mm}$, respectively). On the other hand, the original extract and the $1: 2$ diluted one showed the antibacterial effect against $P$. aeruginosa with the inhibition zones of $9.2 \pm 0.3 \mathrm{~mm}$ and $8.3 \pm 0.6 \mathrm{~mm}$, respectively; whereas the other diluted extracts $(1: 4)$ and (1:6) did not show their inhibitory effect. Moreover, the original and diluted extracts $(1: 2$ and $1: 4)$ exhibited a low antimicrobial effect on $S$. typhimurium (8.3 \pm $1.0 \mathrm{~mm}, 7.3 \pm 0.3 \mathrm{~mm}$, and $7.2 \pm 0.6 \mathrm{~mm}$, respectively), but no inhibitory effect was observed for the $1: 6$ diluted extract. For S.aureus, only the original extract exhibited low antibacterial activity against $S$. aureus $(8.2 \pm$ $0.3 \mathrm{~mm})$, and the other diluted extracts $(1: 2,1: 4$, and 1:6) did not inhibit $S$. aureus growth. An important point to note is that among the 6 bacterial strains, the original extract exhibited a stronger antibacterial effect 
$(9.2 \pm 0.3 \mathrm{~mm}, 10.3 \pm 0.3 \mathrm{~mm}$ and $8.2 \pm 0.3 \mathrm{~mm})$ than the positive control for three strains ( $S$. enteritidis, $B$. cereus, and $S$. aureus) with the inhibition zone diameters of $7.8 \pm 0.3 \mathrm{~mm}, 9.7 \pm 0.3 \mathrm{~mm}$ and $7.2 \pm 0.3 \mathrm{~mm}$, respectively. In contrast, positive control showed stronger antibacterial effects against $S$. typhimurium $(10.8 \pm 0.8 \mathrm{~mm})$ than original extract $(8.3 \pm 0.6 \mathrm{~mm})$. Furthermore, the antibacterial effect of original extract was as strong as that of positive controls against $E$. coli $(9.3 \pm 0.3 \mathrm{~mm})$ and $P$. aeruginosa $(9.2 \pm 0.3 \mathrm{~mm}$ ) (Table 2$)$. These results indicated that the $R$. wittii trunk extract is a potential antibacterial agent.

$R$. wittii is a rare species, and the number of samples is limited. Therefore, the chemical composition and the antibacterial activity of the ethanolic extract of this species have not been studied yet. A previous study by Koagnea et al. (2017) indicated the presence of a diterpenoid rothalazepane in Rothmannia talbotii, a medicinal plant used in the western region of Cameroon as a fever reducer, which was also identified in $R$. wittii in the present study. Furthermore, the antimicrobial activity of ethyl p-methoxycinnamate, which was found in the $R$. wittii extract and Kaempferia galanga, a traditional medicinal herb of India, was also determined (Lakshmanan et al., 2011). The presence of these bioactive compound in $R$. wittii extracts suggests that this species could be a potential source for isolating bioactive compounds, with a possibility of their further application in medicine or as a promising remedy for treating certain diseases such as cancer and infectious diseases (Lakshmanan et al., 2011; Habtemariam et al., 2018). To date, only a few species of Rothmannia genus have been investigated with a focus on their antibacterial activity; for example, Awosan et al. (2014) proved the antimicrobial effect of the methanolic extract of $R$. longiflora leaf against 10 pathogenic fungal and bacterial strains. The lack of evidences of bioactivity and chemical composition of $R$. wittii is a large hindrance to use this species in the industry and medicine. In the present study, we provided more information on the phytochemical composition and bioactivity of one species of Rothmannia genus, and the results could be used as the basis for further applications of $R$. wittii in medicine.

\section{Conclusion}

Ten compounds, namely 1 ) benzene, 1-(1,5-dimethyl4-hexenyl)-4-methyl, 2) diphenylsulfone, 3) 6ß-hydroxy- 10-0-acetylgenipin, 4) cinnamyl-cinnamate, 5) genipin, 6) megastigmatrienone, 7) ethyl p-methoxy-trans-cinnamate, 8) rothalazepane, 9) 1,3,6-trimethylpyrano[2,3- $d$ ] imidazole-2,5(1H,3H)-dione, and 10) shanzhiol were identified in ethanolic wxtract of $R$. wittii trunks. These extracts showed an antibacterial effect against on six tested bacterial strains: Salmonella enteritidis, Bacillus cereus, Pseudomonas aeruginosa, Escherichia coli, Staphylococcus aureus, and Salmonella typhimurium. This study provides information about the chemical composition and bioactivity of the ethanolic extract of $R$. wittii, which constitutes an important basis for further applications of $R$. wittii in medicine.

\section{References}

Altemimi A., Lakhssassi N., Baharlouei A., Watson D.G., Lightfoot D.A. (2017) Phytochemicals: extraction, isolation, and identification of bioactive compounds from plant extracts. Plants 6: 1-23.

Awosan E.A., Lawal I.O, Ajekigbe J.M., Borokini T.I. (2014) Antimicrobial potential of Rothmannia longiflora Salisb and Canna indica Linn extracts against selected strains of fungi and bacteria. Afr. J. Microbiol. Res. 8: 2376-2380.

Bauer A.W., Kirby W.M., Sherris J.C., Turck M. (1996) Antibiotic susceptibility testing by a standardized single disk method. Am. J. Clin. Pathol. 45: 493-496.

Bhatia S.P., Wellington G.A., Cocchiara J., Lalko J., Letizia C.S., Api A.M. (2007) Fragrance material review on cinnamyl cinnamate. Food Chem. Toxicol. 45(11): 66-69.

Bui H.Q., Nguyen T.C. (2015) A new record species Rothmannia wittii (Craib) Bremek. (Rubiaceae) for the flora of Vietnam. J. Biol. 37(4): 458-462.

Chaipukdee N., Kanokmedhakul K., Kanokmedhakul S. (2016) Two new bioactive iridoids from Rothmannia wittii. Fac. Sci. Med. Health 113: 97-101.

Chirangini P., Sinha S.K., Sharma G.J. (2004) Sulfur free radical reactivity with curcumin as reference for evaluating antioxidant properties of medicinal Zingiberales. J. Environ. Path. Toxic. Oncol. 23(3): 235-244.

De U.C., Ghosh R., Chowdhury S. (2012) New iridoid from aerial parts of Mussaenda roxburghii. Natural Prod. Commun. 7(1): 1-2.

Devi R.S., Radhamany P.M., Devi V.G. (2016) Sesamin-an active lignin compound from psilanthes travencorensis, a member of Rubiaceae. Inter. Ayurvedic Med. J. 4: 2891-2897.

Ghosh S., Derle A., Ahire M., More P., Jagtap S., Phadatare S.D., Patil A.B., Jabgunde A.M., Sharma G.K., Shinde V.S., Pardesi K., Dhavale D.D., Chopade B.A. (2013) Phytochemical analysis and free radical scavenging activity of medicinal plants Gnidia glauca and Dioscorea bulbifera. PloS one 8(12): e82529.

Habtemariam S., Lentini G. (2018) Plant-derived anticancer agents: lessons from the pharmacology of geniposide and its aglycone, genipin. Biomedicines 6(2): 1-23. 
Huang L., Yagura T., Chen S. (2008) Sedative activity of hexane extract of Keampferia galanga $L$. and its active com pounds. J Ethnopharmacol. 120(1): 123-125.

Jensen S.R. (1983) Iridoids in Rothmannia globosa. Phytochemistry 22(8): 1761-1765.

Kamazeri T.S., Samah O.A., Taher M., Susanti D., Qaralleh H. (2012) Antimicrobial activity and essential oils of Curcuma aeruginosa, Curcuma mangga, and Zingiber cassumunar from Malaysia. Asian Pac. J. Trop. Med. 5: 202-209.

Kanchanapoom T., Klai-on S., Kasai R. (2002) A new tricyclic iridoid glucoside from the Thai medicinal plant, Rothmannia wittii. Heterocycles 57(12): 2409-2412.

Koagnea R.R., Bitchagnoa G.T.M., Fobofou S.A.T. (2017) Rothtalazepane, a new azepane from the wood of Rothmannia talbotii (Rubiaceae). Natural Prod. Commun. 12(9): 1435-1436.

Lakshmanan D., Werngren J., Jose L. (2011) Ethyl p-methoxycinnamate isolated from a traditional anti-tuberculosis medicinal herb inhibits drug resistant strains of Mycobacterium tuberculosis in vitro. Fitoterapia 82(5): 757-761.

Lalitha S., Parthipan B., Mohan V.R. (2015) Determination of bioactive components of psychotria nilgiriensis Deb \& Gang (Rubiaceae) by GC-MS analysis. Int. J. Pharmacogn. Phytochem. Res. 7(4): 802-809.

Newman M., Ketphanh S., Svengsuksa B. (2007) A check list of the Vascular Plant of Lao PDR. Royal Botanic Garden Edinburgh, Scotland: 314-315.
Nicolaou K.C., Vourloumis D., Winssinger N., Baran P.S. (2000) The art and science of total synthesis at the dawn of the twenty first century. Angew. Chem. Int. Ed. 39: 44-122.

Oladeji O. (2016) The characteristics and roles of medicinal plants: some important medicinal plants in Nigeria. Nat. Prod. Ind. J. 12( 3): 102.

Pham N.K.T., Phan T.M.T., Nguyen K.P.P. (2015) Two new compounds from Hedyotis lindleyana. Natural Prod. Commun. 10(7): 1141-1143.

Pham-Hoang H. (2000) Araceae. [in:] Cây co' Viêt Nam: An illustrated flora of Vietnam. Ed. Pham-hoang H. Youth Publishing House, Ho Chi Minh City, Vietnam.

Ton T.H.T., Nguyen T.T., Dinh T.K.T., Le V.S., Tran G.B., Van H.T. (2019) New distribution records of Rothmannia wittii (Rubiaceae) in Vietnam and identification of DNA barcode sequence for $R$. wittii. Natura Sciences and Technology, Ho Chi Minh City University of Education 16: 190-199.

Uddin N., Hossain M.K., Haque M.R. (2013) Chemical investigation of Paederia foetidae (Rubiaceae). Asian J. Chem. 25(2): 1163-1164.

Wongsatit C., Promchit S., Boonpleng A. (2002) Medicinal plants used in the Loengnoktha district, Yasothon Province, Thailand. Thai J. Phytopharm. 9(2): 24-46. 